\title{
Association of viral hemorrhagic septicemia virus with epizootic hemorrhages of the skin in Pacific herring Clupea harengus pallasi from Prince William Sound and Kodiak Island, Alaska, USA
}

\author{
T. R. Meyers ${ }^{1}$, S. Short ${ }^{1}$, K. Lipson ${ }^{1}$, W. N. Batts ${ }^{2}$, J. R. Winton ${ }^{2}$, J. Wilcock ${ }^{3}$, \\ E. Brown ${ }^{3}$
}

\footnotetext{
${ }^{1}$ Alaska Department of Fish and Game, Division of Commercial Fisheries, Management and Development, Fish Pathology Section, Juneau Fish Pathology Laboratory, PO Box 25526, Juneau, Alaska 99802, USA

${ }^{2}$ U. S. Fish and Wildlife Service, National Fisheries Research Center, Building 204, Naval Station, Seattle, Washington 98115 , USA

${ }^{3}$ Alaska Department of Fish and Game, Division of Commercial Fisheries Management and Development, Cordova, Alaska 99574, USA
}

\begin{abstract}
Only one-third of the Pacific herring Clupea harengus pallasi expected to spawn in Prince William Sound (PWS), Alaska, USA, in spring 1993 were observed. Of these herring, 15 to $43 \%$ had external ulcers or subdermal hemorrhages of the skin and fins. A rhabdovirus identified as the North American strain of viral hemorrhagic septicemia virus (VHSV) was isolated from affected herring and 1 Pacific cod Gadus macrocephalus with skin lesions from PWS, and from herring with similar lesions collected near Kodiak Island. No other pathogens were detected in the herring examined. Although VHSV may have been responsible for the skin lesions, there was no confirmed mass herring mortality observed in PWS; hence the actual cause of the reduced herring numbers is still unknown. The same strain of VHSV was subsequently isolated from captive juvenile herring collected from Auke Bay, Alaska, near Juneau, from herring in British Columbia, Canada, and from Puget Sound, Washington, USA. These findings suggest the virus is an opportunistic pathogen that is widely indigenous to Pacific herring populations in the Pacific Northwest and that herring are a significant marine reservoir for North American VHSV.
\end{abstract}

KEY WORDS: VHSV $\cdot$ Herring $\cdot$ Hemorrhages

\section{INTRODUCTION}

The North American strain of viral hemorrhagic septicemia virus (VHSV) was first isolated in Alaska, USA from skin lesion material of 2 Pacific cod Gadus macrocephalus. These fish were sport-caught in Prince William Sound (PWS), Alaska, during the summers of 1990 and 1991 (Meyers et al. 1992). During April 1993, two-thirds (about $100000 \mathrm{t}$ ) of mostly the 5 yr old (1988 year class) Pacific herring Clupea harengus pallasi expected to return to spawn in PWS failed to appear. Hence, the commercially important seine fishery was never opened for harvest. Among the herring that did return, 15 to $43 \%$ had varying degrees of external ulceration or hemorrhage beneath the skin, at the bases of fins and around the vent, accompanied by lethargic swimming behavior. A rhabdovirus identified as VHSV by serum neutralization, and further identified as the North American strain of VHSV by a strain specific complimentary DNA probe, was isolated from kidney and spleen pools from 2 groups of these herring and from skin and organ samples of a Pacific cod sportcaught nearby. Herring with similar skin and fin hemorrhages were observed near Kodiak Island, Alaska. Subsequently, the same North American VHS virus was isolated from these fish as well, although herring 
returns there and the commercial fishery had been successful. An experiment to examine the potential role of VHSV in herring mortality and lesion production was initiated using 2 yr old herring captured in the wild from Auke Bay, Alaska. However, in the course of the study the uninjected and sham-injected 'negative' control fish were found to carry an apparently identical strain of VHSV.

In this paper we describe the isolation and identification of North American VHSV from Pacific herring, a new host species, and the associated histological lesions of virus-infected herring having skin ulcerations and/or external hemorrhages. The possible epizootiological relationship of herring VHSV with isolates of VHSV from Alaskan Pacific cod and anadromous salmonids from Washing ĝn State, USA, is discusseü. during May 16 and 17, 1993. These fish were kept alive and used for a VHSV transmission study.

A Pacific cod having skin ulcerations was sportcaught on April 25, 1993, in Mud Bay of PWS (Fig. 1). These lesions were typical of those in cod from which North American VHSV had been previously isolated (Meyers et al. 1992). Refrigerated samples of skin lesions, liver and gut were sent to the Juneau ADF\&G pathology laboratory on April 27, 1993.

Virology and cell culture. Kidneys and spleens were aseptically removed from 10 herring collected from Graveyard Point in PWS and from a second group of 10 collected from Red Head. These tissues were pooled separately in groups of 5 and homogenized in a Stomacher (Tekmar). Three pools of kidney/spleen, edcin poul from 3 íish, were made from the 9 Admiraity Island herring while 2 kidney/spleen pools, each from

\section{MATERIALS AND METHODS}

Source of fish. On April 20, 1993, herring with and without skin hemorrhages were collected from Graveyard Point (Fig. 1) off Montague Island in PWS for examination by Alaska Department of Fish and Game (ADF\&G) fish pathologists in Juneau. Most of these fish had not spawned and were transported fresh on ice. Additional PWS herring collected on April 22, 1993, from Red Head were transported fresh with other frozen herring taken on April 21, 1993, from Virgin Bay (Fig. 1). About $83 \%$ of the Virgin Bay fish were spawned-out, $2 \%$ were immature while over $13 \%$ had mature but resorbing gonads. Both the Red Head and Virgin Bay fish were released from netpens used for spawning herring roe on kelp. Herring were collected by variable mesh gillnet, seine or dipnet. Herring having skin hemorrhages were also collected by gillnet from Barling Bay, Kodiak Island (Fig. 1) on April 22, 1993. These fish were frozen, partially thawed to select for hemorrhagic lesions, then frozen again for transport to the Juneau ADF\&G pathology laboratory on May 13, 1993.

On May 5, 1993, normal-appearing 4 to 5 yr old spawning herring were collected live as control fish from Oliver Inlet on Admiralty Island (Fig. 1).

Apparently normal juvenile 2 yr old Pacific herring were dipnetted from a large fish school in Auke Bay (Fig. 1)



Fig. 1. Locations in Alaska, USA, where Pacific herring Clupea harengus pallasi and a Pacific cod Gadus macrocephalus were sampled for skin lesions during April and May, 1.993: (1) Auke Bay; (2) Oliver Inlet; (3) Virgin Bay; (4) Landlocked Bay; (5) Red Head; (6) Mud Bay; (7) Rocky Bay; (8) Graveyard Point; (9) Stockdale Harbor; (10) Port Chalmers; (11) Green Island; (12) Barling Bay 
4 fish, were made from the 8 Kodiak Island herring. A kidney, spleen and liver pool from each of 46 Auke Bay herring juveniles were processed individually. The 2 skin lesions ( 1 on ice; 1 in MEM-O described below) from the single Pacific cod caught in Mud Bay of PWS were processed separately while the liver and gut from the same fish were inadvertently pooled. Homogenized samples were diluted $1: 10$ (w/v) in MEM-O, made up of Eagle's minimum essential medium containing final concentrations of $300 \mu \mathrm{g}$ streptomycin $\mathrm{ml}^{-1}$, $300 \mathrm{IU}$ penicillin $\mathrm{ml}^{-1}, 7.5 \mathrm{\mu g}$ amphotericin $\mathrm{B} \mathrm{ml} \mathrm{m}^{-1}$, $0.3 \%$ of tryptose phosphate broth, $0.04 \mathrm{mM}$ supplemented L-glutamine $\mathrm{ml}^{-1}$ and 8.9 to $14.3 \mathrm{mM}$ sodium bicarbonate. Sample suspensions were then centrifuged at $6000 \times g$ for $20 \mathrm{~min}$. A portion of the supernatants from the Kodiak Island herring samples were passed through a serum-soaked $0.45 \mu \mathrm{m}$ membrane filter due to concerns about excessive contamination. Epithelioma papulosum cyprini (EPC) cell (Fijan et al. 1983) monolayers were grown in 24-well plates in MEM-O containing $10 \%(M E M-10)$ fetal bovine serum (FBS) at $23^{\circ} \mathrm{C}$. Herring samples from both PWS locations were inoculated onto both EPC and chinook salmon Oncorhynchus tshawytscha embryo (CHSE214 ) cells (ATCC CRL 1681) while the Graveyard Point fish were also inoculated onto a third cell line derived from bluegill Lepomis macrochirus fry (BF-2) (Wolf et al. 1966). Both CHSE-214 and BF-2 cells were cultured in the same manner as the EPC cells. Cells were pretreated with polyethylene glycol (PEG) (Batts \& Winton 1989 ) for 10 min at room temperature $\left(23\right.$ to $25^{\circ} \mathrm{C}$ ), then duplicate or quadruplicate wells were inoculated with $0.1 \mathrm{ml}$ volumes of undiluted $(1: 10), 10^{-2}$ and in some cases $10^{-4}$ dilutions of supernatants from the homogenized tissue samples. Inocula were adsorbed onto cells for $1 \mathrm{~h}$ at $14^{\circ} \mathrm{C}$ before addition of $1 \mathrm{ml}$ per well of MEM-10 and a final concentration of $15 \mathrm{mM}$ tris buffer and $5.4 \mathrm{mM}$ sodium bicarbonate. The plates were incubated at $14^{\circ} \mathrm{C}$ in plastic containers with sealed lids for 14 to $21 \mathrm{~d}$. Cultures having no cytopathic effect (CPE) were blind-passaged onto fresh EPC monolayers for an additional $14 \mathrm{~d}$ using $0.1 \mathrm{ml}$ of cell suspension and supernatant from the first dilution well. Estimates of virus titers were determined by the method of Reed \& Muench (1938). The number of replicates determined the minimum detection levels for the various samples: 100 infectious virus particles (IVP) for the Auke Bay herring samples, 30 and 50 IVP for the PWS herring samples and 25 IVP in the Admiralty Island and Kodiak Island herring samples and PWS cod tissues

Transmission electron microscopy (TEM). Remaining cells and debris of EPC monolayers showing extensive CPE from the first pool of the Red Head herring samples were fixed 16 to $18 \mathrm{~h}$ at $4{ }^{\circ} \mathrm{C}$ in $4 \%$ glutaraldehyde in $0.1 \mathrm{M}$ cacodylate buffer ( $\mathrm{pH} 7.8$ ). Cells were post-fixed in cacodylate-buffered $1 \%$ osmium tetroxide for $1 \mathrm{~h}$ at room temperature. Preserved kidney tissues from 2 Auke Bay juvenile herring having histological evidence of erythrocytic inclusions were post-fixed in the same manner. After dehydration through a series of ethanol solutions, the fixed materials were embedded in Spurr's resin and ultra-thin sections mounted onto 300 mesh copper grids. Sample grids stained in $2 \%$ aqueous uranyl acetate and $2.6 \%$ lead citrate were examined with a Philips TEM 300 at $60 \mathrm{kV}$.

Serology: virus neutralization. Plaque-reduction neutralization tests were performed using polyclonal rabbit antisera prepared against the European F1 reference strain of VHSV (from P. McAllister, National Fisheries Research Center, Leetown, West Virginia, USA) and a Cedar River, Washington, isolate of infectious hematopoietic necrosis virus (IHNV) (from National Fisheries Research Center, Seattle, Washington, USA). Each antiserum was tested against the second passage material of herring isolates from Graveyard Point and Red Head, and against a Cedar River isolate of IHNV (from National Fisheries Research Center, Seattle) and a VHSV isolate (from National Fisheries Research Center, Seattle) from the Makah National Fish Hatchery, near Neah Bay, Washington. Detailed methods used for the neutralization assay have been described elsewhere (Meyers et al. 1992).

DNA probe. Monolayer cultures of CHSE-214 or EPC cells were prepared in 24 -well plates and single wells were inoculated with each of the 3 new isolates of VHSV from herring at high multiplicities of infection An isolate of VHSV from Pacific cod in Alaska, 2 reference isolates of IHNV, 2 reference isolates of North American VHSV, 2 isolates of European VHSV, doublestranded DNA product amplified by polymerase chain reaction (PCR) from portions of the $\mathrm{N}$ genes of IHNV and VHSV, and unifected cells served as controls. After $2 \mathrm{~d}$ incubation at $15^{\circ} \mathrm{C}$, total RNA extractions from the infected cells and other sample controls were tested using the nonradioactive DNA probes against VHSV and IHNV described by Batts et al. (1993).

Bacteriology. Kidney tissues of herring from Graveyard Point were aseptically inoculated onto plates of furunculosis agar using standard bacteriologic procedures. Plates were incubated at $23^{\circ} \mathrm{C}$ for at least $5 \mathrm{~d}$ and examined for bacterial growth. Plates of marine agar and yeast extract agar similarly inoculated with kidney material from Red Head herring were incubated in a similar manner.

A direct fluorescent antibody test (FAT) for Renibacterium salmoninarum was also performed on kidney smears from the Graveyard Point herring using methods described by Meyers et al. (1993).

Blood smears and hematocrits. Blood smears were made from most groups of herring soon after their 
death either in the field or in the pathology laboratory after receipt of the fish. Exceptions were the herring from Kodiak Island which were too autolytic for blood or kidney impression smears and the juvenile herring from Auke Bay in which kidney impression smears from previously frozen samples were made as an afterthought. Smears were air dried and stained using Diff-Quik (Dade Diagnostics, Inc., Aquada, Puerto Rico). Erythrocytes were examined by light microscopy for the presence of cytoplasmic inclusion bodies typical of viral erythrocytic necrosis (VEN). Slides were examined at $1000 \times$ magnification and considered negative for VEN if no cytoplasmic inclusions were observed in 30 fields.

Blood from Graveyard Point and Red Head herring was drawn into $60 \mathrm{~mm}$ (i. d. $=0.5$ to $0.6 \mathrm{~mm}$ ) heparinized micro-hemâtocrit capillary tubes âter excisiny the caudal peduncle. Filled capillary tubes were centrifuged $(5500 \times g$ for $10 \mathrm{~min})$ and hematocrits determined by using a plastic micro-hematocrit capillary tube reader.

Necropsy and histology. Laboratory necropsies of whole herring included external examination of all surfaces and orifices, wet mounts of gills and skin and internal examination of viscera with wet mounts of spleen and gut. Wet mounts were not made from Kodiak Island herring due to post-mortem autolysis.

Tissues collected for histology from PWS herring examined in the laboratory included kidney, liver, and spleen preserved in Bouin's fixative for several days followed by transfer to $70 \%$ ethanol. Kidneys and livers preserved from the Admiralty Island herring were used for comparative controls. Tissues from PWS herring preserved in $10 \%$ buffered formalin by field biologists included intact skin and underlying musculature of external lesions, kidney, liver and spleen from individual flish. Tissues were preserved only from PWS herring having external lesions of the skin and fins, most of which were collected from the Graveyard Point and Green Island sites (Fig. 1). Standard histological procedures were used for tissue dehydration and paraffin embedment. Cut sections on glass slides were stained with hematoxylin and eosin (H\&E).

Virus transmission study. A virus transmission experiment was initiated to examine whether the VHSV isolate from herring could produce lesions and mortality in apparently normal herring following waterborne challenge or intraperitoneal injection. Two-year-old herring netted from Auke Bay were maintained in an indoor $750 \mathrm{l}$ recirculating seawater tank chilled to $10^{\circ} \mathrm{C}$. Sufficient numbers of fish were collected in $2 \mathrm{~d}$ and then half of the group was moved to an identical recirculating covered tank located in an outdoor compound at the ADF\&G Juneau fish pathology laboratory. The herring in the building were challenged with the virus. The herring in the outdoor tank were nega- tive controls that included uninjected fish and those inoculated with $0.1 \mathrm{ml}$ of sterile MEM-10 after brief anesthesia. Herring from virus-challenged and control groups that died during the $24 \mathrm{~d}$ in captivity were either frozen at $80^{\circ} \mathrm{C}$ or preserved in Bouin's fixative for subsequent histology. Further details regarding methodology for the virus-exposed group of fish are not provided since much of that data was invalidated by subsequent isolation of VHSV from the negative control group of herring.

\section{RESULTS}

\section{Virus isolation}

Cytupdthic eifects simiiar to those caused by VHSV from Pacific cod (Meyers et al. 1992) were evident after $7 \mathrm{~d}$ in EPC cells receiving the second kidney/spleen pool of the Graveyard Point herring (Table 1). BF-2 cells inoculated with the same sample showed CPE after $10 \mathrm{~d}$, however the CHSE-214 cells showed no $\mathrm{CPE}$ after $14 \mathrm{~d}$. Both cell lines exhibiting CPE were positive in the highest dilution wells of $10^{-3}$. The first sample pool remained negative in all 3 cell lines despite a blind passage on EPC cells.

The second pool made from Red Head herring caused CPE after $3 \mathrm{~d}$ in EPC cells and by Day 4 in CHSE-214 cells. The first pool also caused CPE initially in EPC cells after $4 \mathrm{~d}$ followed by CHSE-214 cells a day later (Table 1 ). Both pools produced CPE in wells with the highest dilution of the inoculum $\left(10^{-3}\right)$. Titration of the original samples indicated the second pool had the highest virus titer of $3.16 \times 10^{5} \mathrm{TCID}_{50} \mathrm{ml}^{-1}$

The Kodiak Island herring samples procuced CPE after $13 \mathrm{~d}$ in 1 of 4 wells of EPC cells inoculated with the first pool. The positive well was 1 of 2 receiving inoculum filtered through a $0.45 \mu \mathrm{m}$ membrane filter. No virus was isolated from the Admiralty Island herring (Table 1).

In the virus transmission study, examination of individual Auke Bay herring indicated that $43 \%$ (Tables 1 \& 2) of 46 fish examined from the control tank were positive for VHSV with estimated titers ranging from just detectable (100 IVP) to $10^{7} \mathrm{ml}^{-1}$. Virus-positive herring included 19 of 45 MEM-10 injected fish and 1 of 7 extra uninjected fish held in a separate compartment. High titered virus-positive fish had been in captivity for as few as $3 \mathrm{~d}\left(10^{4} \mathrm{ml}^{-1}\right)$ and $4 \mathrm{~d}\left(10^{6} \mathrm{ml}^{-1}\right)$ and as long as $11 \mathrm{~d}\left(10^{4} \mathrm{ml}^{-1}\right)$. Virus-negative fish had been in captivity for as long as $24 \mathrm{~d}$ (Table 2).

Skin lesion material from the Mud Bay cod received on ice produced CPE in EPC cells after $9 \mathrm{~d}$ while the gut/liver pool produced CPE as early as $5 \mathrm{~d}$. No virus was isolated from the cod skin lesion received in MEM-10. 
Table 1. Clupea harengus pallasi. Results of necropsy and virological examination of Alaskan Pacific herring from various locations that were examined for viral hemorrhagic septicemia virus (VHSV) in April and May 1993

\begin{tabular}{|c|c|c|c|c|c|c|}
\hline \multirow[t]{2}{*}{ Sample site } & \multicolumn{3}{|c|}{ Mean values } & \multicolumn{3}{|c|}{ Observations } \\
\hline & $\begin{array}{l}\text { Total length } \\
\quad(\mathrm{mm})\end{array}$ & $\begin{array}{l}\text { Weight } \\
\text { (g) }\end{array}$ & $\begin{array}{c}\text { Hematocrit } \\
(\%)\end{array}$ & Bacteria & VEN & $\begin{array}{l}\text { VHSV } \\
\text { (pool) }\end{array}$ \\
\hline \multicolumn{7}{|c|}{ Prince William Sound } \\
\hline \multicolumn{7}{|c|}{ Graveyard Point } \\
\hline Lesions & $254(10)^{\mathrm{b}}$ & $112(10)$ & $57(10)$ & $0 / 15$ & $0 / 29$ & $1 / 2$ \\
\hline No lesions & $199(20)$ & 97 (19) & $N^{c}$ & ND & $0 / 28$ & ND \\
\hline \multicolumn{7}{|l|}{ Virgin Bay } \\
\hline Lesions & $196(10)$ & $93(10)$ & ND & ND & $0 / 10$ & ND \\
\hline No lesions & $198(10)$ & $93(10)$ & ND & ND & $2 / 10$ & ND \\
\hline \multicolumn{7}{|l|}{ Red Head } \\
\hline Lesions & 272 & 126 & $46 \quad(4)$ & $0 / 5$ & $0 / 5$ & $2 / 2$ \\
\hline \multicolumn{7}{|l|}{ Kodiak Island } \\
\hline Lesions & ND & ND & ND & ND & ND & $1 / 2$ \\
\hline \multicolumn{7}{|c|}{ Admiralty Island } \\
\hline No lesions & ND & ND & ND & ND & $0 / 10$ & $0 / 2$ \\
\hline \multicolumn{4}{|l|}{ Auke Bay } & ND & $7 / 10$ & $20 / 46^{e}$ \\
\hline $\begin{array}{l}\text { a Number posit } \\
{ }^{b} \text { Number of fis } \\
\text { c Not done } \\
\text { d Lesions on sn } \\
\text { e Individual fish }\end{array}$ & $\begin{array}{l}\text { to mechanical } \\
\text { er than pooled }\end{array}$ & $\begin{array}{l}\text { Iry in capti } \\
\text { aples }\end{array}$ & & & & \\
\hline
\end{tabular}

Table 2. Clupea harengus pallasi. Daily mortality and prevalence of viral hemorrhagic septicemia virus (VHSV) in juvenile Auke Bay herring held captive as unexpose virus controls

\begin{tabular}{|ccc|}
\hline $\begin{array}{c}\text { Days in } \\
\text { captivity }\end{array}$ & $\begin{array}{c}\text { Daily } \\
\text { mortality }\end{array}$ & $\begin{array}{c}\text { Prevalence of } \\
\text { VHSV }\end{array}$ \\
\hline 2 & 4 & $0 / 4$ \\
3 & 4 & $3 / 4$ \\
4 & 2 & $1 / 2$ \\
5 & 8 & $3 / 8$ \\
6 & 12 & $7 / 12$ \\
7 & 11 & $5 / 8$ \\
8 & 1 & $0 / 1$ \\
9 & 1 & $0 / 1$ \\
11 & 3 & $1 / 2$ \\
13 & 1 & $0 / 1$ \\
21 & 1 & $0 / 1$ \\
24 & 1 & $0 / 2$ \\
a Number positive/number examined \\
\hline
\end{tabular}

In all samples, CPE was often slight or absent in the lowest dilution (undiluted, i.e. $10^{-2}$ ) suggesting incomplete virus particle interference. Passage of all virus isolates produced CPE with estimated titers of $10^{6}$ to $10^{7} \mathrm{ml}^{-1}$ after $7 \mathrm{~d}$. CPE occurred more quickly and frequently in EPC cells than in CHSE-214 cells.

\section{Transmission electron microscopy}

Thin sections of EPC cells inoculated with second passage material from Red Head herring showed numerous rhabdovirus particles within vacuoles and at cell peripheries which were similar to those observed previously from Pacific cod (Meyers et al. 1992). Thin sections of erythrocyte inclusions in kidneys of the 2 Auke Bay juvenile herring indicated iridovirus type particles typical of VEN.

\section{Virus identification}

Plaque reduction tests with the Graveyard Point and Red Head herring virus isolates showed that the infectivity of both was reduced at least $3 \log _{10}$ by antiserum against the European VHSV F1 strain. Both control IHN and VHS viruses were significantly neutralized by their homologous antisera.

Fig. 2 shows 3 nitrocellulose strips each identically spotted with the same virus samples but reacted with different DNA probes. The probe specific for an $\mathrm{N}$ gene sequence of the North American strain of VHSV reacted with the mRNA extracted from cells infected with the Makah and 1990 PWS cod isolates as well as 


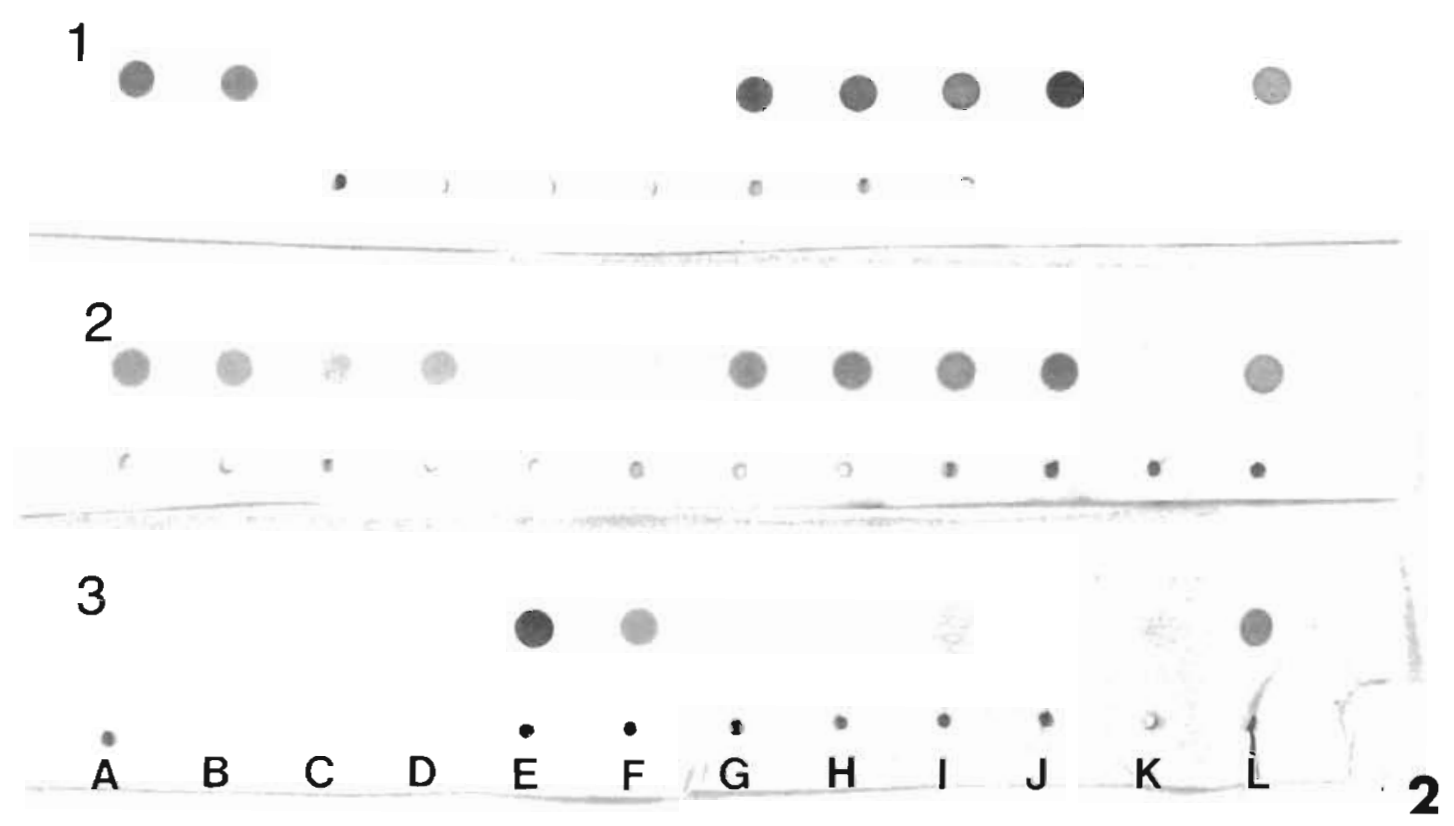

Fig. 2. DNA probe assay: nitrocellulose strips were spotted with 3 isolates of VHSV from Pacific herring Clupea harengus pallasi, 1 VHSV isolate from Pacific cod Gadus macrocephalus, 4 isolates of reference VHSV and 2 isolates of reference IHNV. They were reacted with the North American VHSV DNA probe (strip 1), European VHSV DNA probe (strip 2) and an IHNV DNA probe (strip 3). All viruses were replicated in either EPC or CHSE-214 cells for $48 \mathrm{~h}$. Strips 1, 2 and 3: (A) 1988 Makah National Fish Hatchery, Washington reference VHSV; (B) 1990 Pacific cod reference isolate of VHSV from Prince William Sound (PWS), Alaska; (C) 1971 European 07-71 reference VHSV from France; (D) 1975 European 23-75 reference VHSV from France; (E) 1980 Cedar River, Washington, reference IHNV; (F) 1976 Round Butte, Oregon, reference IHNV; (G) 1993 Pacific herring VHSV isolate from Graveyard Point, PWS; (H) 1993 Pacific herring VHSV isolate from Red Head, PWS; (I) 1993 Pacific cod VHSV isolate from Mud Bay, PWS; (J) 1993 Pacific herring VHSV isolate from Barling Bay, Kodiak Island, Alaska; (K) MEM-10; (L) homologous PCR positive control

with the 2 PWS herring and 1993 cod isolates, the Kodiak Island herring isolate and a positive control consisting of a PCR product for the North American VHSV strain. No reaction was observed with mRNA of the 2 IHNV and 2 European VHSV isolates or with the negative MEM-10 control. Strip 2 was reacted with the DNA probe recognizing an $N$ gene sequence common to all VHSV isolates. This probe reacted with mRNA from all VHSV samples and with the PCR product serving as a positive control but it did not react with mRNA extracted from IHNV infected cells or with the negative MEM-10 control. Strip 3 was developed using the IHNV probe which reacted only with the 2 IHNV samples and the IHNV PCR positive control. The Auke Bay herring isolate was also identified as a North American strain of VHSV by the same DNA probe (results not shown).

\section{Bacteriology and FAT}

No microbial growth was observed on any of the bacteriological media inoculated with kidney material from 15 fish representing the 2 groups of PWS herring
(Table 1). Renibacterium salmoninarum was not detected by FAT in 10 kidneys from the Graveyard Point herring.

\section{Examination of blood for VEN}

No evidence of VEN was observed in blood smears from 10 normal-appearing Admiralty Island herring, and only 2 of the 82 blood smears examined from PWS herring had low levels of VEN-like viral inclusions (Table 1). Mean hematocrits of $57 \%$ and $46 \%$ from 14 PWS herring having skin hemorrhages were within normal values (Table 1 ).

\section{Necropsy and histology of adult herring}

Over 3000 spawning or spawned herring were collected from 8 locations in PWS (Fig. 1) and examined in the field from April 17 to 23, 1993. The fish showed varying prevalences of hemorrhagic skin lesions, some with ulceration, that ranged from minor to extensive: $22 \%$ from Stockdale Harbor, $15.5 \%$ from Green Island, $37 \%$ from Port Chalmers, $32 \%$ from Rocky Bay, 


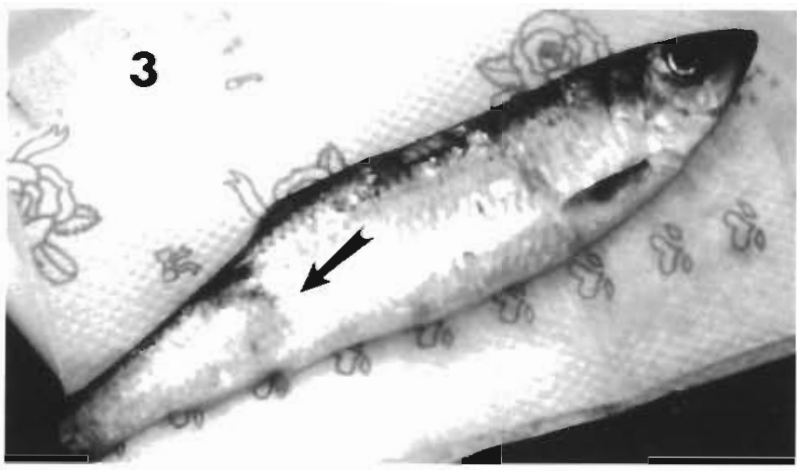

Fig. 3. Clupea harengus pallasi. Pacific herring from Graveyard Point, Prince William Sound, Alaska, showing a ventral subdermal hemorrhage (arrow) probably caused by infection with viral hemorrhagic septicemia virus (VHSV)

$42.5 \%$ from Graveyard Point, $5.2 \%$ from Virgin Bay, $36.7 \%$ from Red Head and $25 \%$ from Landlocked Bay. No mass herring mortality was documented but there were unconfirmed reports of a large number of bones, or other herring remains, on the beaches of Port Chalmers (Fig. 1). All herring were smaller in size and weight than expected from projections based on samples taken during the previous fall bait fishery (ADF\&G unpubl. data).

Fifteen herring collected from Graveyard Point showed varying degrees of obvious hemorrhaging in the fins and beneath the skin extending midway to the posterior of the body (Fig. 3). None of the 5 herring randomly selected for necropsy showed any internal abnormalities except for encysted nematodes in the viscera numbering from 1 to 8 per fish. Twenty-five affected herring collected from Red Head had very minor external abnormalities including frayed fins and an occasional small round subsurface skin hemorrhage. No other external or internal visceral abnormalities were observed during necropsies of 5 of these fish. All 8 herring received from Kodiak Island had varying degrees of skin hemorrhages, some of which were exacerbated by gillnet damage and post-mortem autolysis. Tissue autolysis also prevented any further assessment of potential lesions in the internal organs of these fish.

A total of 79 PWS herring with external hemorrhages were examined histologically. Microscopic lesions in cluded varying degrees of passive congestion in large vessels and sinusoids of the liver $(67 / 79=85 \%)$, spleen $(50 / 74=68 \%)$ and kidney $(44 / 70=63 \%)$. Diffuse, single-cell hepatocyte necrosis was present in 10 of the 67 congested livers while 23 others had various-sized active melanomacrophage foci comprised of reticuloendothelial (RE) type cells. We defined 'active' foci as immunologically stimulated and having some or all of the following features: unpigmented RE cells; irregular margins and association with necrotic hepatocytes (Fig. 4); peripheral infiltration of lymphocytes (Fig. 5); accumulation of eosinophils within RE foci; and association of foci immediately adjacent to congested vessels and sinusoids. In some fish, these foci of RE cells were very large, displacing sinusoidal tissue with similar foci of RE cells in the spleen, kidney (Fig, 6) and subcutis of the skin. The subcutis lesions also included hemorrhaging (Fig 7) and necrosis. The more typical yellowbrown pigmented, round, smooth-margined liver melanomacrophage foci were common and often abundant as well.

Of 44 congested kidneys, 21 had some degree of hemorrhaging (Fig. 8) while 24 had minor to extensive degeneration and pyknosis of the tubular epithelium (Fig. 9). RE cell foci were present in 8 of the congested kidneys (Fig. 6). Of 50 congested spleens, 6 had some hemorrhaging and 3 had RE cell proliferation as indicated above. Typical yellow-brown pigmented melanomacrophage foci were common and often very abundant.

Skin tissues from 41 fish were examined histologically. Lesions present within the subcutis and underlying skeletal musculature included capillary congestion in 15 fish, hemorrhage in 11 fish (Fig. 7) and RE cell infiltration in 26 fish with some associated necrosis in 4 of these fish

Incidental histologic findings included: encapsulated tubercular-type granulomas containing stages of Ichthyophonus hoferi in most tissues of 4 fish; 32 livers with mostly low numbers of encysted Eimeria clupearum, generally with no host response except infrequent association with the typical pigmented melanomacrophage foci; pansporoblasts of unidentified myxosporideans in the gall bladder of 1 fish and in the kidney mesonephric ducts of 3 fish; unidentified nematodes encysted in the mesenteries of 2 fish.

In addition to being virus-negative, 10 Admiralty Island herring were also normal in appearance externally and internally. Hence, their liver and kidney tissues were compared to histological findings reported from virus-positive herring above. Histological observations included: in livers, minor passive congestion of the large vessels in 2 fish, 3 fish infected by Eimeria clupearum and 1 fish with Icthyophonus hoferi granulomas; in kidneys, 1 fish with unidentified myxosporidean pansporoblasts in the mesonephric ducts. Typical melanomacrophage centers in the liver were fewer than in the PWS tissues.

\section{Auke Bay experimental herring}

Control herring received MEM-10 sham injections on their second day of captivity. The experiment was terminated after fish were in captivity for $24 \mathrm{~d}$ with 

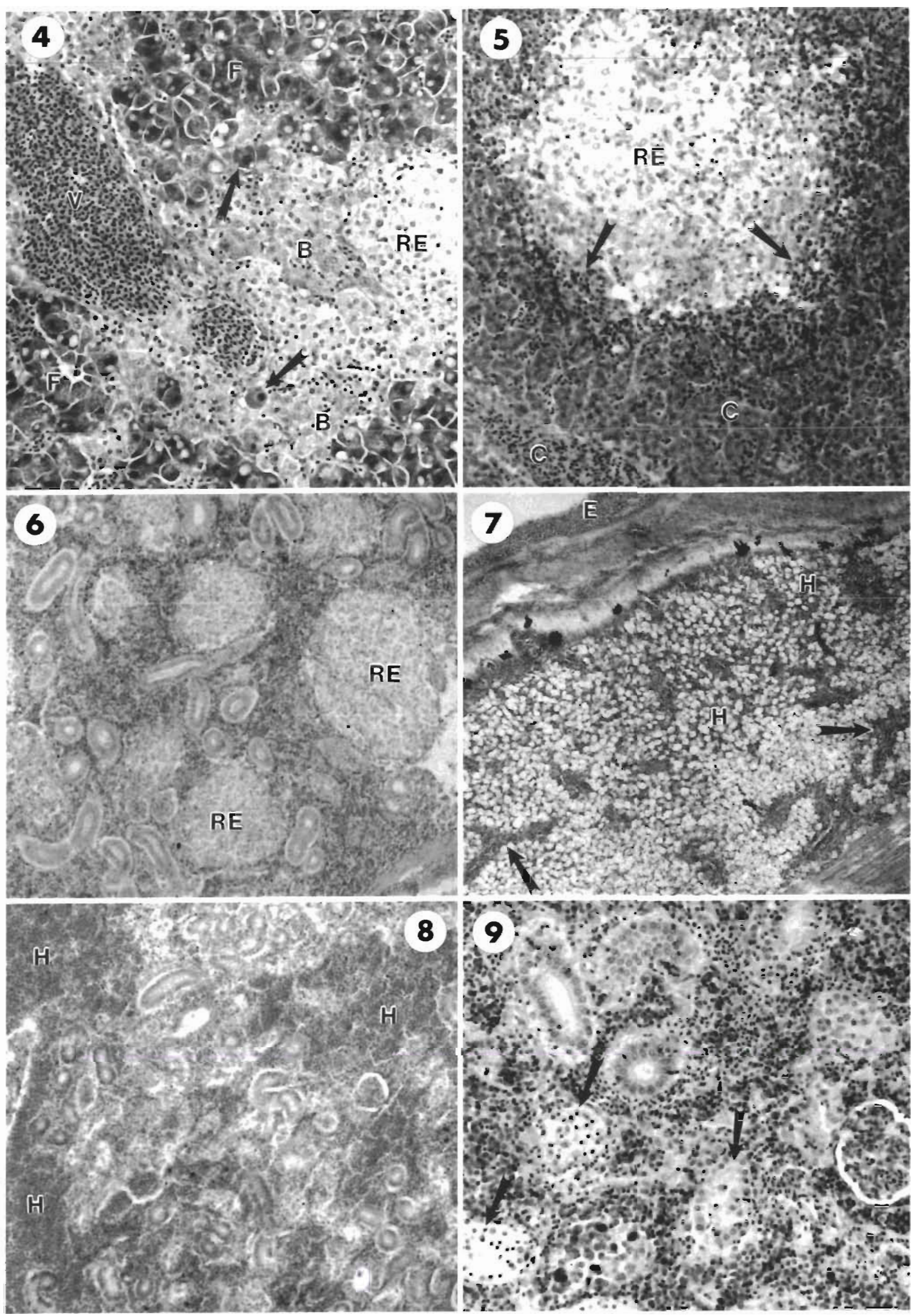
only 3 survivors in the control group. Most fish that died had obvious frayed caudal fins and/or eroded snouts accompanied by hemorrhages. These lesions were apparently due to trauma caused by fish bumping the retaining screens, however some fish died with no obvious external lesions. Daily mortality ranged from 3 fish at 3 d of captivity to a peak of 8,12 and 11 fish at 6,7 and $8 \mathrm{~d}$ of captivity $(3,4$ and $5 \mathrm{~d}$ after sham injection). Mortality thereafter was sporadic, ranging from none to 3 fish at $11 \mathrm{~d}$. Interestingly, the days of peak mortality in control fish coincided with increasingly high percentages of VHSV-positive fish among those examined (Table 2). Although blood smears were not collected from the Auke Bay herring, histological sections from 10 of $18 \mathrm{VHSV}$-injected and MEM control fish showed VEN-type inclusions within numerous immature erythrocytes occurring in the livers and kidneys. Stained kidney impressions made later from 10 additional frozen herring used in the experiment indicated a $70 \%$ prevalence of VEN-type inclusions. This may have been a conservative estimate due to autolysis of cells after freeze-thawing.

This experiment established that VHSV was already present within the Auke Bay herring and that a concomitant VEN infection was also present as indicated by erythrocyte inclusions and confirmatory TEM.

\section{DISCUSSION}

The DNA probe results confirmed that all 7 virus isolates from Pacific herring and Pacific cod were members of the North American strain of VHSV. Until this study, VHSV in Alaska had been isolated from only 2 Pacific cod from PWS and only from external skin lesions (Meyers et al. 1992) despite examination of over 100 cod from various areas in Alaska including PWS (Meyers et a]. unpubl. data). Hence, the rarity of VHSV in Pacific cod, and the nonsystemic nature of the virus in the 1 infected cod where organs were examined, suggested the virus was a secondary pathogen replicating in epidermal cells and that infection was by exposure to some other external source of the virus. The latter speculation was confirmed by our isolations of VHSV from herring over wide geographic areas in Alaska which established the Pacific herring as a new host species for North American VHSV. More recently the virus has been isolated from herring in British Columbia, Canada (Traxler \& Kieser 1994) and Puget Sound, Washington, USA (J. R. Winton \& W N. Batts pers. comm.), indicating that the Pacific herring may be a major marine reservoir for VHSV throughout the Pacific Northwest.

Whether VHSV played any role in reducing the number of herring returning to PWS has not been established nor has there ber:I verification of major herring mortality except for unconfirmed reports However, our data offer some evidence to support that the virus may have been responsible for the high prevalences of external skin and fin lesions and lethargic behavior observed in herring returning to PWS. In these fish, VHSV was present in high titers, indicative of active replication in host tissues, and no other likely fish pathogens were isolated or observed. Higher virus titers and minor external lesions present in the Red Head herring may have been due to an earlier viremic stage of infection in which obvious external lesions had not yet developed. Conversely, only 1 sample pool of the Graveyard Point herring had a detectable level of virus but external lesions in these fish were more extensive. This condition could have represented a later stage of VHSV infection with less detectable virus present, possibly due to the action of host defenses such as interferon (de Kinkelin et al. 1982). Neutralizing antibody as a protective host defense against VHSV (Vestergaard-Jørgensen 1971) was not tested for in the PWS herring. However, in subsequent examination of pooled sera from VHSV-infected herring from Puget Sound, Washington, homologous neutralizing antibody was not detected (W. N. Batts \& J. R. Winton unpubl. data).

The histopathological features of subdermal and kidney hemorrhages, kidney tubule degeneration and active RE cell foci in the livers and kidneys of PWS herring suggested viremia due to a weakly pathogenic virus. The minor extent of these lesions was not typical of VHS in salmonids and certain marine species where the virus is strongly endotheliotrophic (Liversidge \& Munro 1978, de Kinkelin et al. 1979) causing extensive hemorrhaging of skin and other tissues, degenerative changes and necrosis primarily in the kidney, spleen and liver (Wolf 1988). Aithough necrosis can include kidney tubule epithelium where replication of VHSV has been demonstrated (de Kinkelin et al. 1979, Kruse

Figs. 4 to 9. Clupea harengus pallasi. Hematoxylin and eosin tissue sections Pacific herring from Prince William Sound, Alaska, having external skin lesions similar to that shown in Fig. 3. Fig. 4. Liver with reticuloendothelial (RE) cell focus adjacent to congested vasculature (V), hypertrophied hepatocytes with fatty change (F), bile duct hyperplasia (B) and hepatocyte pyknosis (arrows); $\times 212$. Fig. 5 . RE cell focus $(\mathrm{RE})$ in congested liver (C) with peripheral infiltration of lymphocytes (arrows); $\times 212$. Fig. 6 . Kidney with RE cell foci (RE); $\times 112$. Fig. 7 . Subcutis with vascular congestion (arrows) and hemorrhage (H) into adipose tissue; intact epidermis $(\mathrm{E}) ; \times 43$. Fig. 8. Kidney with hemorrhage $(\mathrm{H}) ; \times 43$. Fig. 9. Kidney with degeneration of tubules and cell pyknosis (arrows): $\times 212$ 
\& Neukirch 1989), insterstitial kidney necrosis is generally present as well. Lesions caused by VHSV described in other fish were more like those we observed in PWS herring, including proliferative foci of macrophages in the kidney and vascular congestion of the kidney and liver (Wolf 1988). The RE cell foci we observed were mostly in the livers of PWS herring and were not unlike RE cell granulomas described in the livers of rainbow trout recovering from an experimental avirulent reovirus infection (Meyers 1983). Much of the passive congestion that we observed in the livers and spleens of most herring examined could have been due to post-mortem changes. However, the tissues of some herring collected at the same time had no congestion while other fish had likely ante-mortem lesions including diffuse hepatocyte necrosis and hidney tubular degeneration associated with more extensive passive congestion. These features suggest that some of the passive congestion may have occurred before death of the fish.

The epizootiology of VHSV in herring may be that of an opportunistic pathogen causing periodic disease after host stress from several factors that were present in various combinations in the populations of fish examined. These stressors included disease caused by other infectious agents such as VEN, spawning, capture or nutritional deficiency through lack of forage. The latter condition was likely present in PWS herring based on the smaller expected size of fish that returned. Some unknown amount of mortality must occur during these epizootics, based on the moribund behavior observed in PWS herring having skin hemorrhages and ulcers. Death would likely be caused by osmoregulatory collapse and/or secondary microbial infections resulting from the ulcerating skin lesions.

A similar host/parasite relationship occurs with VEN in Pacific herring, where the virus is prevalent among many populations but only causes occasional epizootic mortality in juvenile fish when they are stressed (Meyers et al. 1986). Auke Bay is one such area where 2 yr old herring have sustained past epizootics of VEN (Meyers 1989). VEN was inexplicably absent in most adult herring that we examined except for low levels of erythrocytic inclusions in $20 \%$ of the fish from Virgin Bay that had no external lesions (Table 1). The prevalence of subclinical VEN in normal-appearing 3 to $5 \mathrm{yr}$ old Alaskan herring has ranged from $17 \%$ to $80 \%$ with no associated mortality or external lesions (Meyers et al. 1986).

Isolation of VHSV from our experimental control Auke Bay herring confounded any interpretation of the other virus exposure portions of the study. We are confident that these control fish were naturally infected because great care was taken in their handling and physical isolation after capture to prevent accidental exposure to the virus. Also, the very high virus titers detected in control fish dying after only 3 to $4 \mathrm{~d}$ in captivity were not likely to have developed in such a short period following an accidental exposure. More likely, the cumulative stress of handling, captivity and a concomitant VEN infection exacerbated a preexisting, natural VHSV infection that may have contributed to daily mortality which peaked $7 \mathrm{~d}$ after capture. However, the same stressors probably had a similar effect on the VEN virus which may have caused some of the mortality in the captive fish as well.

Waterborne transmission of VHSV is likely to occur if other fish species are in the immediate vicinity of large herring schools comprised of many thousands of virusinfected fish. This concept is based on reports of gills and epidermal ceilis of the skin and fins as major portals of entry for horizontal transmission of VHSV (Wolf 1988, Yamamoto et al. 1992). Recent studies have also shown replication of endogenous herring VHSV to over 1000 -fold in excised herring fins after $72 \mathrm{~h}$ and to 100 -fold in excised epidermis after $7 \mathrm{~d}$ ( J. R. Winton \& W. N. Batts unpubl. data). Another likely route of horizontal virus transmission would be from eating infected herring, a major forage species for many predator fishes such as cod and salmon. Consequently, frozen whole bait herring would be a potential source for dissemination of virus, as demonstrated by the survival of VHSV in the Kodiak Island herring after 2 conventional freeze-thaw cycles. Our most recent isolation of VHSV from both skin lesion and internal organ materials of a third Pacific cod from PWS suggested a systemic infection by the virus. However, if this cod had been feeding on VHSV-infected herring the virus may have been present in the gut material that was inadvertantly pooled with the liver. For this reason, systemic infection by VHSV in Pacific cod has not been conclusively established.

The widespread occurrence of VHSV in Pacific herring offers an attractive explanation for the isolations of VHSV from adult coho Oncorhynchus kisutch and chinook $O$. tshawytscha salmon returning to Washington State during 1988, 1989 and 1991 (Brunson et al. 1989, Hopper 1989, Winton et al. 1989, 1991, Eaton \& Hulett 1990, Stewart et al. 1990). Because the North American strain of VHSV appears to be indigenous in Pacific herring populations, it is likely that the virus will be detected again in salmonids. Additional studies are needed to determine the seasonal distribution of VHSV among stocks of Pacific herring throughout the Pacific Northwest.

Previous injection. studies indicated that the Washington isolates of VHSV are relatively avirulent for selected salmonids (Winton et al. 1991). Waterborne exposure studies with the 1990 Alaskan Pacific cod isolate showed a similar avirulence for certain 
Pacific salmon species but the virus did infect rainbow trout Oncorhynchus mykiss, causing a chronic mortality of $20 \%$ over a 30 d period (Meyers et al, unpubl. data). Rhabdoviruses are noted for their ability to evolve rapidly. Hence, North American VHSV has the potential to become a significant pathogen of trout and salmon if the virus is subjected to strong selective pressures as might occur during the course of intensive fish culture practices. It is possible that the European strain of VHSV also came from the marine environment where it adapted to become a virulent pathogen of rainbow trout after unpasteurized marine fish were used as a food source for hatchery fish. This exact route of adaption is not as likely today in North America with the use of high quality processed fish foods, bot nonetheless conservative methods should be employed to eradicate the virus whenever detected in salmonids.

Acknowledgement. We thank Mrs Ruth Fairall of Cordova, Alaska, for submitting the Pacific cod material used in this study.

\section{LITERATURE CITED}

Batts, W. N., Arakawa, C. K., Bernard, J., Winton, J. R. (1993). Isolates of viral hemorrhagic septicemia virus from North America and Europe can be detected and distinguished by DNA probes. Dis. aquat. Org. 17: 67-71

Batts, W. N., Winton, J. R. (1989). Enhanced detection of infectious hematopoietic necrosis virus and other fish viruses by pretreatment of cell monolayers with polyethylene glycol. J. Aquat. Anim. Health 1: 284-290

Brunson, R., True, K., Yancey, J. (1989). VHS virus isolated at Makah National Fish Hatchery. Fish Health Sect. Am. Fish. Soc. Newsl. 17(2): 3

de Kinkelin, P., Chilmonczyk, S., Dorson, M., Le Berre, M., Baudouy, A. M. (1979). Some pathogenic facets of thabdoviral infection of salmonid fish. In: Bachman, P. (ed.) Proceedings of the 4th Munich symposium on microbiology: mechanisms of viral pathogenesis and virulence. WHO Collaborating Centre for Collection and Evaluation of Data on Comparative Virology, Munich, p. 357-375

de Kinkelin, P., Dorson, M., Hattenberger-Baudouy, A. M. (1982). Interferon synthesis in trout and carp after viral infection. Dev. comp. Immunol. Suppl. 2: 167-174

Eaton, W. D., Hulett, J. (1990). The fourth (and fifth?) isolation of viral hemorrhagic septicemia virus in Washington State. Fish Health Sect. Am. Fish. Soc. Newsl. 18(1): 3

Fijan, N., Sulimanovic, D., Bearzotti, M., Muzinic, D., Zwillenberg, L. O., Chilmonczyk, S., Vautherot, J. F., de Kinkelin, P. (1983). Some properties of the Epithelioma papulosum cyprini (EPC) cell line from carp Cyprinus carpio. Ann. Virol. Inst. Pasteur 134: 207-220

Hopper, K. (1989). The isolation of VHSV from chinook salmon at Glenwood Springs, Orcas Island, Washington. Fish Health Sect. Am. Fish. Soc. Newsl. 17(2): 1

Kruse, P., Neukirch, M. (1989). The significance of rainbow trout brain and excretory kidney for the propagation of

Responsible Subject Editor: F. M. Hetrick, College Park, Maryland, USA viral hemorrhagic septicemia (VHS) virus. In: Ahne, W. Kurstak, E. (eds.) Viruses of lower vertebrates. SpringerVerlag, Berlin, p. 367-378

Liversidge, J., Munro, A. L. S. (1979). The virology of teleosts In: Roberts, R. J. (ed.) Fish pathology. Bailliere Tindall, London, p. 114-143

Meyers, T R. (1983). Serological and histopathological responses of rainbow trout, Salmo gairdneri Richardson, to experimental infection with the $13_{22}$ reovirus. J. Fish. Dis. 6: $277-292$

Meyers, T R. (1989). Reoccurrence of VEN epizootics in Alaskan Pacific herring. Fish Health Sect. Am. Fish. Soc. Newsl. 17 (3): 9

Meyers, T. R., Hauck, A. K., Blankenbeckler, W. D., Minicucci, T. (1986). First report of viral erythrocytic necrosis in Alaska, USA, associated with epizootic mortality in Pacific herring, Clupea harengus pallasi (Valenciennes). J. Fish. Dis. 9: 479-491

Meyers, T. R., Short, S., Farrington, C., Lipson, K., Geiger, H. J., Gates, R. (1993). Comparison of the enzyme-linked immunosorbent assay (ELISA) and the fluorescent antibody test (FAT) for measuring the prevalences and levels of Renibacterium salmoninarum in wild and hatchery stocks of salmonid fishes in Alaska, USA. Dis. aquat. Org. 16: 181-189

Meyers, T R., Sullivan, J., Emmenegger, E., Follett, J., Short, S. Batts, W. N., Winton, J. R. (1992). Identification of viral hemorrhagic septicemia virus isolated from Pacific cod Gadus macrocephalus in Prince William Sound, Alaska, USA. Dis. aquat. Org. 12: 167-175

Reed, L. J., Muench, H. (1938). A simple method of estimating fifty percent endpoints. Am. J. Hyg. 27: 493-502

Stewart, B. B., Olson, C., Lutz, S. (1990). VHS virus detected at Lummi Bay Sea Ponds, Bellingham, Washington. Fish Health Sect. Am. Fish. Soc. Newsl. 18(1): 2

Traxler, G. S., Kieser, D. (1994). Isolation of the North American strain of viral hemorrahagic septicemia virus (VHSV) from herring (Clupea harengus pallasi) in British Columbia. Fish Health Sect. Am. Fish. Soc. Newsl. 22(1): 8

Vestergaard-Jørgensen, P. E. (1971). Egtved virus: demonstration of neutralizing antibodies in serum from artificially infected rainbow trout (Salmo gairdneri). J. Fish. Res. Bd Can. 28: 875-877

Winton, J. R, Batts, W. Deering, R., Brunson, R., Hopper, K., Nishizawa, T., Stehr, C. (1991). Characteristics of the first North American isolates of viral hemorrhagic septicemia virus. Second International Symposium on Viruses of Lower Vertebrates. Oregon State University, Corvallis, p. $43-50$

Winton, J. R., Batts, W. N., Nishizawa, T., Stehr, C. M. (1989). Characterization of the first North American isolates of viral hemorrhagic septicemia virus. Fish Health Sect. Am. Fish. Soc. News]. 17 (2): 2

Wolf, K. (1988). Fish viruses and fish viral diseases. Cornell University Press, Ithaca

Wolf, K., Gravell, M., Malsberger, R. G. (1966). Lymphocystis virus: isolation and propagation in centrarchid fish cell lines. Science 151: 1004-1005

Yamamoto, T., Batts, W. N., Winton, J. R. (1992). In vitro infection of salmonid epidermal tissues by infectious hematopoietic necrosis virus and viral hemorrhagic septicemia virus. J. Aquat. Anim. Health 4: 231--239 